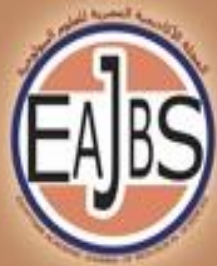

EGYPTIAN ACADEMIC JOURNAL OF
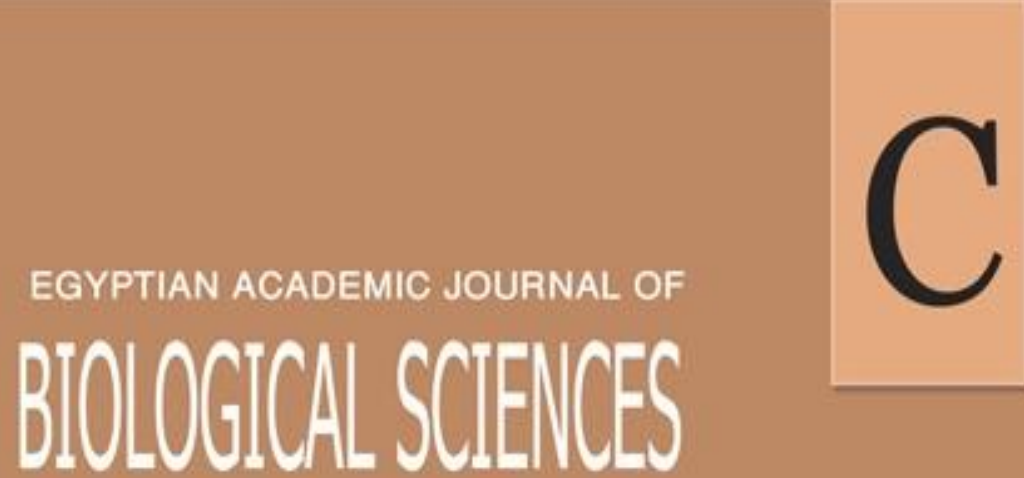

PHYSIOLOGY \& MOLECULARBIOLOGY
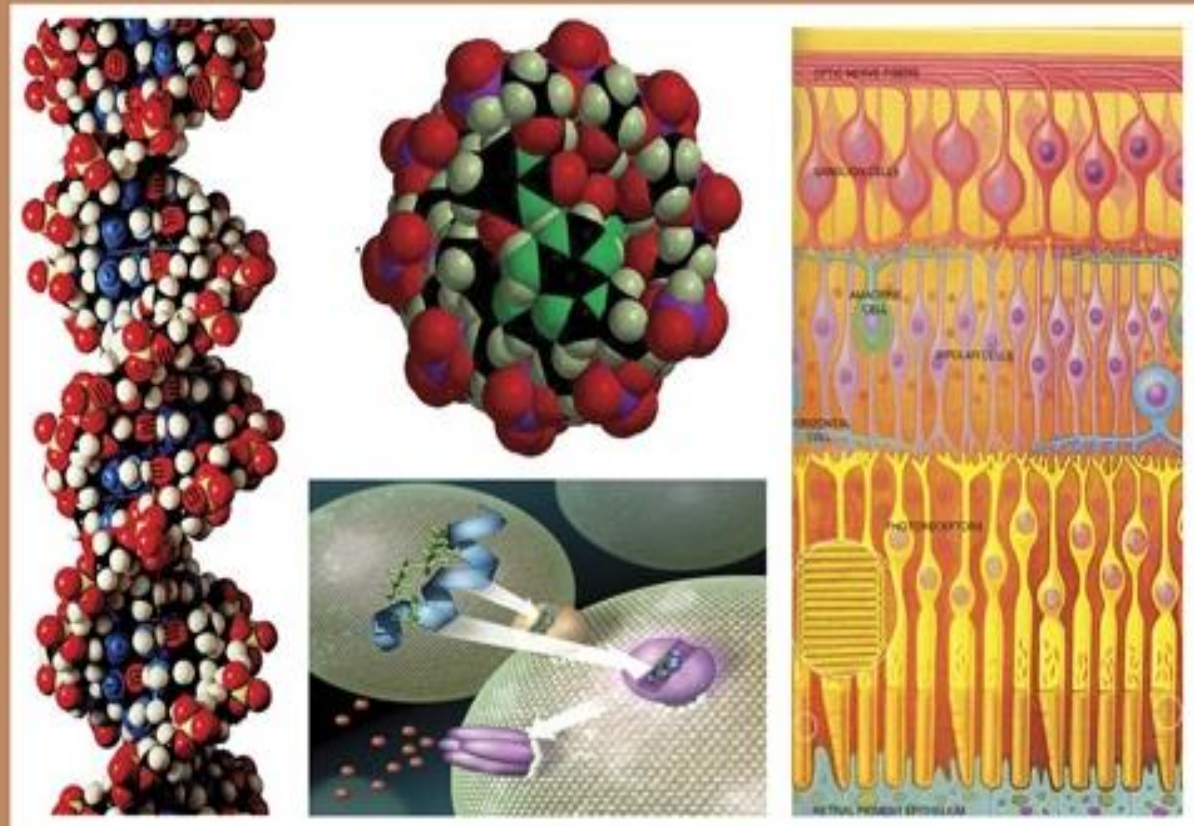

ISSN

2090-0767

WWW.EAJBS.EG.NET

Vol. 14 No. 1 (2022) 
Egypt. Acad. J. Biolog. Sci., 14(1):91-106 (2022)

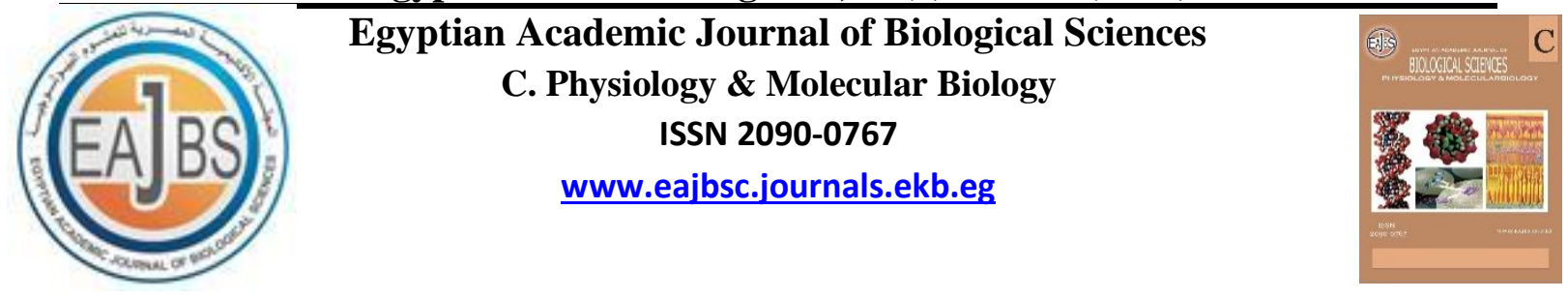

\title{
Biochemical and Physiological Reactions for Field Strain of Cotton Leafworm, Spodoptera littoralis (Boisd.) as An Exposure-Response to Temperature Under Climatic Change
}

\author{
Hassan F. Dahi' ${ }^{1}$ Ahmed M. A. Salman²; Hany A. Fouad ${ }^{2}$ and Abdel Rahman M. \\ H. Elgedawy 1 \\ 1-Plant Protection Research Institute, Agricultural Research Center, Dokki, Giza, Egypt \\ 2- Plant Protection Department, Faculty of Agriculture, Sohag University, Egypt \\ *E. Mail: hassandahi@yahoo.com
}

\begin{abstract}
ARTICLE INFO Article History

Received:1/1/2022

Accepted:19/1/2022

Available:22/1/2022

Keywords:

Cotton leafworm, temperature, biochemical parameters, proteins, lipids, carbohydrates, free amino acids, GST, GOT, AchE

\section{ABSTRACT}

It is important to understand the effects of temperatures on Egyptian cotton leafworm Spodoptera littoralis (Boisd.) (Lepidoptera: Noctuidae) which damages a wide variety of crops in the Middle East and is one of the major economic pests of cotton in Egypt. Therefore, the investigating was designed to study the effect of fluctuation temperatures on the field strain in Abnob city, Assuit Governorate during the 2017 and 2018 cotton growing seasons. On the other hand, the results compared with the laboratory strain under constant temperature $\left(25^{\circ} \mathrm{C}\right)$. The biochemical parameters were measured on the $4^{\text {th }}$ larval instars for both strains. Biochemical analyses were performed to determine the effects of fluctuation and constant temperatures on field and laboratory strain on total proteins, lipids, carbohydrates and free amino acids as well as metabolic digestive, neural and detoxification enzymes. It's clear from the results that the GST, GOT, AchE, Alpha esterases, Beta esterases as well as, the activity levels were increased significantly by field strain. While the free amino acids, total proteins, proteases, lipases, amylase were decreased significantly by field strain and no significant changes were detected between field and laboratory strains in total carbohydrates, total lipids, trehalase and GPT.
\end{abstract}

\section{INTRODUCTION}

Climate changes are considered the most important factors that affected insects in terms of physical fitness and metabolism Rinehart et al., 2000. Temperature is a profound biotic environmental factor that induces physiological changes in insects resulting in rapid metabolic variation, which can lead to disorders affecting their lives Parmesan and Yohe 2003. Many authors concluded that, as a result of global warming, the frequency and degree of appearance of high temperatures are predicted to increase substantially Easterling et al., 2000 and Deffenbaugh, 2005. In addition, Parmesan, 2006 noted that the change of climate may cause insect species to spread at the mean rate of $6.1 \mathrm{~km}$ per decade. It can influence insect pests and the size of damage caused by them: directly through their development, reproduction and distribution and indirectly by altering host physiology and defining mechanisms. Moreover, temperatures tend to enhance insect survival because they accelerated metabolism which may lead to higher consumption, growth, and development rates. 
Faster development, in turn, may lead to population increases via reduced generation time and decreased warmer late winter and early-spring Bale et al., 2002. Metabolism, growth and reproduction increase exponentially with warming. Global warming is producing increases in both average temperatures and in the frequency and severity of heatwaves Stone et al., 2010. Moreover, because insects can be killed by short exposure to an extremely high temperature, heat treatments can be applied to control horticultural and stored-product pests, with few insecticidal applications, decreasing the environmental threat, Cui et al., 2008 and Hansen et al., 2011. Recent studies by many authors suggested that the conditions in the upper elevation and also in higher latitude would become more suitable for organisms, because global warming will exceed the threshold of tolerance, in almost all insect species, which, in turn, accelerates cellular energetic demands, Englund et al., 2011; Lemoine and Burkepile, 2012. Insect metabolic rates are highly sensitive to temperature, roughly doubling with an increase of $10^{\circ} \mathrm{C}$ across the full range of regularly experienced temperatures Berggren et al., 2009. Temperature affects diffusion, membrane fluidity, nucleic acid stability, salt and gas solubility, and, significantly, the behaviour of enzymes Lee et al., 2007. The Egyptian cotton leafworm, Spodoptera littoralis is distributed throughout the world. It is a serious or major pest of cultivated crops primarily in tropical and subtropical regions, in Africa, Southern Europe, the Middle East and Asia Pineda et al., 2004. S. littoralis is one of the major economic pests of cotton in Egypt that causes considerable damage to many other vegetables and crops Dahi et al., 2009. S. littoralis, attacks all major crops in Egypt, including cotton, clover, corn, cabbage, cowpea, castor bean, sweet potato, lettuce, tomato, pepper, okra, mulberry, soybeans, etc. El-Aswad et al., 2003. Biochemical parameters such as total proteins, lipids, carbohydrates and free amino acids as well as the activity levels of enzyme groups (metabolic, digestive, nervous and detoxifying enzymes) are among the most important characteristics that may change with global warming (climate change) Aida et al., 2018. The aim of the study was to observe the changes that resulted from climatic changes in the previous years on the cotton leafworm $S$. littoralis biochemical parameters

MATERIALS AND METHODS Maintenance of Spodoptera littoralis Culture (laboratory strain):-

The original colony of the cotton leafworm $S$. littoralis was obtained from a well-established culture at the Department of Cotton Leafworm; Plant Protection Research Institute. The insects were maintained under constant conditions of $25 \pm 2^{0}$ C, $70 \pm 5 \%$ R.H. and 12:12 (L: D) photoperiod, separately. Larvae were reared on fresh castor oil leaves, (Ricinus communis L.) supplied daily in sufficient amounts. Maintenance of the different developmental stages was conducted according to the method described by Gamil, 2004.

\section{Biochemical Bioassay (Sample Preparation): 1-Apparatus:}

Insects were homogenized for biochemical analysis in a chilled glass Teflon tissue homogenizer after homogenation, supernatants these larvae were then homogenized in phosphate buffer (PH.7) were kept in a deep freezer at $-20^{\circ} \mathrm{C}$ till used for biochemical assays. A double beam ultraviolet/visible spectrophotometer was used to measure the absorbance of coloured substances or metabolic compounds.

\section{2-Preparation of Insects for Analysis:}

The insects were prepared as described by 
Amin 1998. They were homogenized in distilled water $(50 \quad \mathrm{mg} / 1 \mathrm{ml})$. Homogenates were centrifuged at 8000 r.p.m. for $15 \mathrm{~min}$ at $2{ }^{\circ} \mathrm{C}$ in a refrigerated centrifuge. The deposits were discarded and the supernatants, which are referred to as enzyme extract, can be stored at least one week without appreciable loss of activity when stored at less than zero ${ }^{\circ} \mathrm{C}$.

-Total soluble protein as described by Bradford (1976)

-Total carbohydrates according to Dubois et al., (1956).

-Total lipids according to Knight et al., (1972).

-Free Amino acid assayed by ninhydrin reagent according to Lee and Takabashi (1966).

\section{Enzymes Assay:}

The Following Enzymes

Activities Were Determined:

-Proteases activity was measured as described by Lee and Takabashi (1966) and Tatchell et al., (1972).

-Carbohydrates hydrolysing enzymes; as described by Dubois et al., (1956)., Crompton and Birt (1967).

-Amylase, Trehalase and Invertase were determined by the method of Ishaaya and Swiriski (1976) and Amin, (1998) using starch, trehalose and sucrose as substrates.

-Lipase activity was measured as described by Knight et al., (1972).

-Acetyl choline-esterase activity was determined using acetylcholine bromide $(\mathrm{AChBr})$ as substrate according to the method described by Simpson et al., (1964).

-Non-specific $\alpha$ and $\beta$ esterase activities were measured as described by Asperen, (1962) using $\alpha$ naphthol acetate and $\beta$ naphthol acetate, respectively, as substrates.

-Glutathione S-transferase activity (GST) was determined spectophotometrically at $340 \mathrm{~nm}$ according to the method of Habig et al. (1974).

-Glutamic pyruvic transaminase (GPT) and glutamic oxaloacetic transaminaseReitman and Frankel 1957.

- (GOT) were determined calorimetrically according to the method of Reitman and Frankle (1957)

Statistical Analysis:

Data from all experiments were subjected to analysis of variance (ANOVA) Using the computer program SAS (Statistical Analysis Systems).

\section{RESULTS AND DISCUSSION}

Field stress (climate change) is considered one of the most important factors affecting the field strain of $S$. littoralis due to the different and fluctuating temperatures and nitrogen ratios that it is exposed to before affecting the type of food. Temperature rise leads to increased metabolic rate, thus decreasing the development period and causing an increase in stored foods Lale et al., 2003; Taveras et al., 2004; Khrüt et al., 2006; Coracini et al., 2007. In addition, a number of physiological stress responses occur in insects as a result of variations in temperature. One reaction to thermal stress is the generation of reactive oxygen species (ROS), which can be harmful by causing oxidative damage. as reported by Ali et al., 2017. Data in Fig.1 indicate the average monthly temperatures during 2017 and 2018 cotton growing seasons at Assuit Governorate and the field strain of $S$. littoralis exposure to these averages of temperatures during the two successive seasons. 


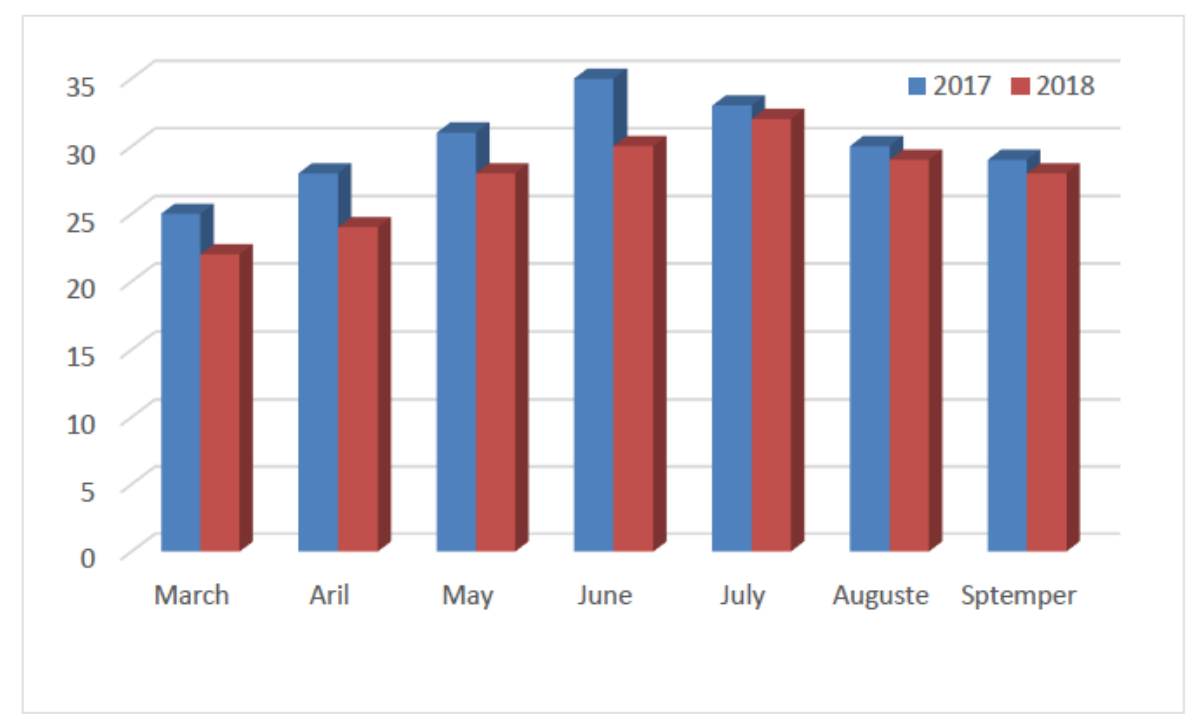

Fig. 1: The monthly average of temperature during 2017 and 2018 cotton growing seasons at Assuit Governorate

\section{Biochemical Analysis:}

Climate change, especially temperature, is one of the most important factors profound effects on chemical and biochemical reactions Hochachka and Somero, 2002. The higher kinetic energy of biochemical reactions speeds up the rate of metabolic processes, scaling up to affect the physiology and behavior of individual organisms Angilletta, 2009. Protein has always been an interesting biochemical tool for insect biochemists because of its potential role in growth, development, morphogenesis and many intermediaries of the metabolic pathway of insects, Kar et al., 1994.

Results in Table. 1 \& Fig. 2 (A) indicated that the levels of total proteins recorded in haemolymph of $4^{\text {th }}$ larval instars in field strain represented by $(23.34 \pm 1.78) \mathrm{mg} / \mathrm{g} . b . w t$, was less than the laboratory strain recorded (31.34 \pm 0.89 ). These results explained by Aida et al., 2018 revealed that $S$. littoralis growth rates increase with Field stress and the larvae consume more protein-rich diets. The results obtained here agree with the finding of Kingsolver, 2006 and Lee and Roh2010.

Also, similar were recorded by, Nagata and Kobayashi 1990 had reported an increase in protein synthesis during the feeding stage in bombyx mori in haemolymph and increased the soluble protein level during pupal development could be attributed to the compensatory replacement of protein that utilized for the formation of pupation. Moreover, Martin et al., 1969 reported the increase of protein levels in haemolymph during oncogenic development of $5^{\text {th }}$ larval instars of silkworm bombyx mori. The increase of protein levels of haemolymph is due to the synthesis of new proteins by tissue and release into haemolymph. Hachiya et al., 2007 reported that proteins denature more rapidly at higher temperatures, which, in turn, requires greater rates of protein synthesis and repair to maintain basic cellular function. In contrast, Malik and Malik 2009 were found when the larvae and pupae were exposed to selected higher temperatures a significant decrease in the protein levels of haemolymph. A relatively higher increase in the free amino acid levels in the haemolymph presumably provides protective cover to tissues against high temperature by an increase in osmolality and reduction in evaporative water loss. On the other hand, Kiran et al., 1998 reported that the fat body synthesizes a number of proteins and releases them into the haemolymph during the active larval 
period. This clearance was confirmed by Willmer et al., 2004 they reported that high temperature affected all biological processes including the structure of proteins and biological members and rates of biochemical and physiological reactions. Moreover, Gullan and Cranston, 2005 concluded the high temperature tended to kill insects cells by denaturing proteins, altering membrane, enzyme structures and properties, by the loss of water (dehydration) and they offer a rich potential for pest management strategies. While the previous study carried by Neven 2000 on the codling moth. The moth subjected to acute heat treatments had a maximal carbon dioxide evolution rate, respiration increase in response to increasing temperatures to a critical upper limit. After this point, respiration decreased. So, death occurs soon after the respiration rate drop even if the insect returned to a normal thermal condition indicating that death cells, death is occurring and denatured protein. Lepidopteran larvae may be particularly vulnerable to environmental warming because their rapid growth rates demand high protein foods Lee et al., 2004 Ehsan et al., 2011 were revealed the fourth larval instars of Pistachio white leaf borer reared at $25^{\circ} \mathrm{C}$ had a lower level of glycogen and a higher level of protein in comparison with those larvae reared at $35^{\circ} \mathrm{C}$. Glycogen is a storage form of energy; therefore, temperature rise leads to increase metabolic rate, decrease development period and cause an increase in stored foods. Protein content in larvae reared at $25^{\circ} \mathrm{C}$ was significantly higher than those reared at $35^{\circ} \mathrm{C}$, but glycogen content in the larvae reared at $35^{\circ} \mathrm{C}$ was more than larvae reared at $25^{\circ} \mathrm{C}$.

In the present study, the number of total lipids as seen inTable.1 \& Fig. 2(B) were recorded in haemolymph and are no significant changes in the total lipid levels recorded between field strain and laboratory strain $(5.64 \pm 0.21)$ and $(5.84 \pm 0.25)$ respectively. These results may be due to an increase in food consumption at lower degrees of temperatures to provide energy (laboratory strain). These results agree with the findings. Hochachka and Somero, 1973., revealed the increase in the contents of total lipids, free fatty acids and phospholipids to increase in food consumption The increase in free fatty acids may provide the lipoprotein enzymes, with an environment to modulate the latter's activity at low temperature. On the other hand, many authors Ellis et al., 2002; Costamagna and Landis, 2004 reported that the orders Lepidoptera and orthoptera use lipids and stored carbohydrates as the main energy source. Lee and Roh 2010 concluded that lipids storage efficiency was lower in larvae of Spodoptera exigua at $18^{\circ} \mathrm{C}$ than at $26{ }^{\circ} \mathrm{C}$, and was similar to those at 34 ${ }^{\circ} \mathrm{C}$. Dooremalen et al., 2011 found that in Philosamia ricini, lipid composition may be an important trait underlying fitness response to temperature, because it affects membrane fluidity as well as the viability of stored energy reserves. With the observed increase in the phospholipid content, larvae showed greatly increased activity of those mitochondrial enzymes which were membrane-associated, and thus the former retained their reticular structures intact during cold exposure. Therefore, Philosamia ricini larvae were exposed to a higher temperature of $35^{\circ} \mathrm{C}$, monovalent cations like $\mathrm{Na}+$ and $\mathrm{K}+$ increased whereas divalent cations like $\mathrm{Ca} 2+$ and $\mathrm{Mg} 2+$ decreased, the percent changes were observed being more at $36^{\circ} \mathrm{C}$ than at highest at $31^{\circ} \mathrm{C}$. The haemolymph monovalent captions were hyper-feeding larvae and divalent captions were hypo-regulated at the quantity of silk synthesized by their silk glands.

The results in Table. 1 \& Fig. 2(C), revealed that the amount of total carbohydrates recorded in haemolymph and is no significant changes in the total carbohydrates levels recorded that field 
and laboratory strain were $(19.27 \pm 0.22)$ and $(19.34 \pm 0.4) \mathrm{mg} / \mathrm{g}$. b.wt respectively. These results disagree with Sonmez and Gulel 2008, they concluded that a low temperature decreases the total carbohydrates and protein amounts of the pest Acanthoscelides obtectus. They recommended that Storage should be kept at $10-15^{\circ} \mathrm{C}$ so that, A. obtectus and other possible pests give minimal damage to crops.

In the current study as seen in Table.1 \& Fig. 2 (D), it is clear that the levels of free amino acids had significant changes less in the haemolymph of fourth larval instars in field strain they were $(372 \pm$ 5.69 ) $\mathrm{mg} / \mathrm{g}$. b.wt. then the laboratory strain was $(432.34 \pm 12.47) \mathrm{mg} / \mathrm{g} . b . w t$ These results agree with Michiyo et al., 1997, they concluded that a low temperature decreases the effects of temperature, diapause and aerobic conditions on the levels of amino acids in overwintering larvae were analyzed. Amino acids levels rose at low temperature on the larval of $E$. leucotaeniella.

Table 1: The activity levels of biochemical in $4^{\text {th }}$ S. littoralis larval instars for field and laboratory strains.

\begin{tabular}{|c|c|c|c|c|}
\hline Strains & $\begin{array}{c}\text { Total proteins } \\
\text { mg/g.b.wt } \\
\text { Mean } \pm \text { SE }\end{array}$ & $\begin{array}{c}\text { Total lipids } \\
\text { mg/g.b.wt } \\
\text { Mean } \pm \text { SE }\end{array}$ & $\begin{array}{c}\text { Total } \\
\text { carbohydrates } \\
\text { mg/g.b.wt } \\
\text { Mean } \pm \text { SE }\end{array}$ & $\begin{array}{c}\text { Free amino acids } \\
\text { Ug alanine/ml } \\
\text { Mean } \pm \text { SE }\end{array}$ \\
\hline Field strain & $23.34 \pm 1.78^{\mathbf{b}}$ & $5.64 \pm 0.21^{\mathbf{a}}$ & $19.27 \pm 0.22 \mathbf{a}^{\mathbf{a}}$ & $372 \pm 5.69^{\mathbf{b}}$ \\
\hline $\begin{array}{c}\text { laboratory } \\
\text { strain }\end{array}$ & $31.34 \pm 0.89^{\mathbf{a}}$ & $5.84 \pm 0.25^{\mathbf{a}}$ & $19.34 \pm 0.45^{\mathbf{a}}$ & $432.34 \pm 12.47^{\mathbf{a}}$ \\
\hline \multicolumn{3}{|c|}{ Note: Means with the same letter in the same column are not significantly different } \\
\hline
\end{tabular}

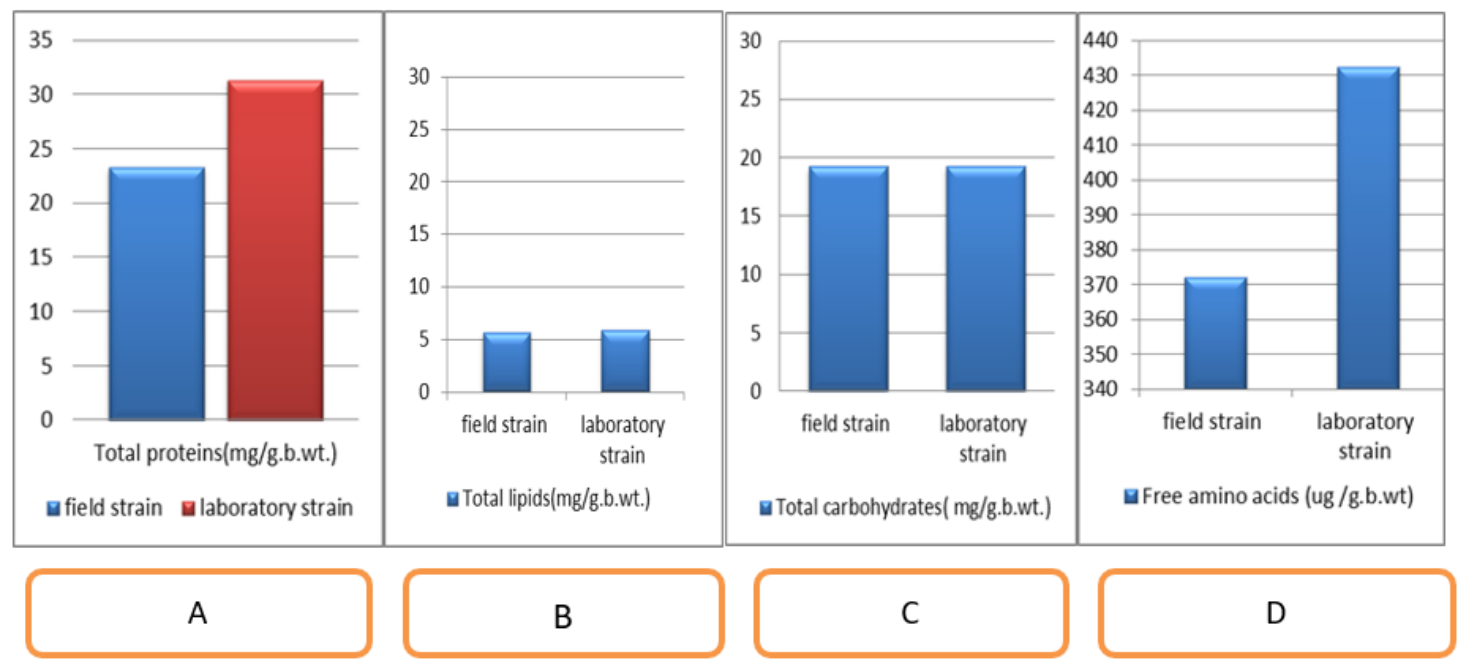

Fig. 2: The activity levels of biochemical of $S$. littoralis $4^{\text {th }}$ larval instar for field and laboratory strains.

\section{Enzyme Assay:}

The optimum temperature for enzyme reactions is generally defined as the temperature at which the maximum reaction rate is achieved Takaya, 2005. The fact that each enzyme behaves differently under various temperature regimes highlights the fact that each enzyme has an optimum temperature activity. Carbohydrate hydrolyzing enzymes (amylase, trehalase and invertase), proteases, and lipases are the 
three main enzymes involved in the digestion of food by insects Callaghan et al., 2002.

The results obtained here that recorded in Table $2 \&$ Fig. 3 (A and B) the activities of the carbohydrate hydrolysing enzymes (amylase, Trehalase) levels that recorded in haemolymph were no significant changes in field strain for laboratory strain $(133.67$ $\pm 1.21),(135 \pm 3.47) \mathrm{mg} / \mathrm{g} . b . w t$ for amylase and trehalase $(164.67 \pm 7.76)$, ( $165 \pm 2.31) \mathrm{mg} / \mathrm{g}$.b.wt. As for invertase in Table 2 \& Fig. 3 (C) the activity levels of were increased significantly in field strain $(912.0 \pm 6.62) \mathrm{mg} / \mathrm{g} . \mathrm{b} . \mathrm{wt}$ than laboratory strain $(852.7 \pm 7.58)$ mg/g.b.wt.

Proteases, which are also known as endopeptidases, enrol an important function in protein digestion. These enzymes begin the protein digestion process by breaking internal bonds in proteins. The amino acid residues vary along the peptide chain, therefore, different kinds of proteinases are necessary to hydrolyze them. Based on the active site group and their corresponding mechanism, digestive proteinases can be classified as serine, cysteine, and aspartic proteases Terra and ferreira, 2012. In the current study in Table 2 \& Fig. 3 (D) appeared that the activity levels of protease enzymes were decreased significant in field strain (19.7 $\pm 0.93) \mathrm{mg} / \mathrm{g} . \mathrm{b} . \mathrm{wt}$ than laboratory strain $(23.04 \pm 0.8) \mathrm{mg} / \mathrm{g}$. b.wt. Pant and Gupta 1979 noted that a significant reduction in enzyme level at field strain that had high proteolytic activity in the second larval instar of Philosamia Ricini declined steadily till late $5^{\text {th }}$ instar development. The decrease was attributed to the composition of food ingested. The low proteolytic activity was due to the host plants which are rich sources of amino acids and which are consumed in large quantities by this insect. The two major proteases classes in the digestive systems of phytophagous insects are the serine and cysteine proteases Haq et al., 2004. Moreover, Srinivasan et al., 2008 had reported on the midgut enzymes of various pests belonging to Lepidoptera. Serine proteases are known to dominate the larval gut environment and contribute to about $95 \%$ of the total digestive activity in Lepidoptera.

$$
\text { Lipases (triacylglycerol-acyl- }
$$

hydrolase EC 3.1.1.3), which catalyzes the hydrolysis of fatty acid ester bonds, are widely distributed among animals, plants and microorganisms Naumff, 2001. In the present study as seen in Table 2 \& Fig. 3 (E), the activity levels of lipase in the midgut of larvae increased significantly in laboratory strain than field strain $(40.3 \pm 0.46)$ and $(36.4 \pm 1.4)$ Ug oleic acid/g.b.wt, respectively. These results disagree with the finding of some previous authors Aida et al., 2018 recorded the activity levels decreased significantly when the temperature raised at 25,30 and $35^{\circ} \mathrm{C}$. They were 820.33 , 810.0 and $789.0 \mathrm{Ug}$ oleic acid/g.b.wt respectively .There were significant changes between them. Ishaaya et al., 1971 concluded that enzymatic activity increased when the temperature rose from 10 to $32^{\circ} \mathrm{C}$. At $10^{\circ} \mathrm{C}$ (i.e. below the threshold of larval development), both proteolytic and amyl lytic activities in the midgut wall were less than 10 percent of that obtained at $32^{\circ} \mathrm{C}$.

Detoxification enzymes in insects are generally demonstrated as the enzymatic defense against foreign compounds and play a significant role in maintaining their normal physiological functions Mukanganyama et al., 2010. Several defensive mechanisms and biochemical reactions are involved in the detoxification processes against any temperature Stress. These mechanisms predominantly involve either metabolic detoxification of the temperature stress before it reaches their damage or the sensitivity changes of the larvae. The most common metabolic resistance mechanisms involve esterases, 
glutathione S-transferases (GSTs). Generally speaking, the increase of activity of detoxification enzymes is the most universal resistant mechanism in insects. An elevation in the activity of such enzymes but surprisingly, this assumption couldn't be achieved as GST relatively decreased exposed to a different constant temperature. GSTs also play an important role in stress physiology and have been implicated in intracellular transport and various biosynthetic pathways Wilce and Parker, 1994.

Table 2: The activity levels of digestive enzymes of $4^{\text {th }}$ larval instars $S$. littoralis in field and laboratory strains.

\begin{tabular}{|c|c|c|c|c|c|}
\hline Strains & $\begin{array}{c}\text { Protease Ug } \\
\text { alanine/min/g.b.wt } \\
\text { Mean } \pm \text { S.E }\end{array}$ & $\begin{array}{c}\text { Lipase Ug oleic } \\
\text { acid/g.b.wt } \\
\text { Mean } \pm \text { S.E }\end{array}$ & $\begin{array}{c}\text { Invertase Ug } \\
\text { glucose/min/g } \\
\text {.b.wt Mean } \pm \\
\text { S.E }\end{array}$ & $\begin{array}{c}\text { Trehalase Ug } \\
\text { glucose/min/g. } \\
\text { b.wt } \\
\text { Mean } \pm \text { S. E }\end{array}$ & $\begin{array}{c}\text { Amylase Ug } \\
\text { glucose/min/g. } \\
\text { b.wt Mean } \\
\pm \text { S.E }\end{array}$ \\
\hline Field strain & $19.7 \pm 0.9^{\mathbf{b}}$ & $36.4 \pm 1.4^{\mathbf{a}}$ & $912.0 \pm 6.62^{\text {a }}$ & $164.67 \pm 7.76^{\mathbf{a}}$ & $133.67 \pm 1.21^{\mathbf{a}}$ \\
\hline $\begin{array}{c}\text { Laboratory } \\
\text { strain }\end{array}$ & $23.04 \pm 0.8^{\mathbf{a}}$ & $40.3 \pm 0.46^{\mathbf{b}}$ & $852.7 \pm 7.58^{\mathrm{b}}$ & $165 \pm 2.31^{\mathbf{a}}$ & $135 \pm 3.47^{\mathbf{a}}$ \\
\hline \multicolumn{5}{|c|}{ Note: Means with the same letter in the same column are not significantly different } \\
\hline
\end{tabular}
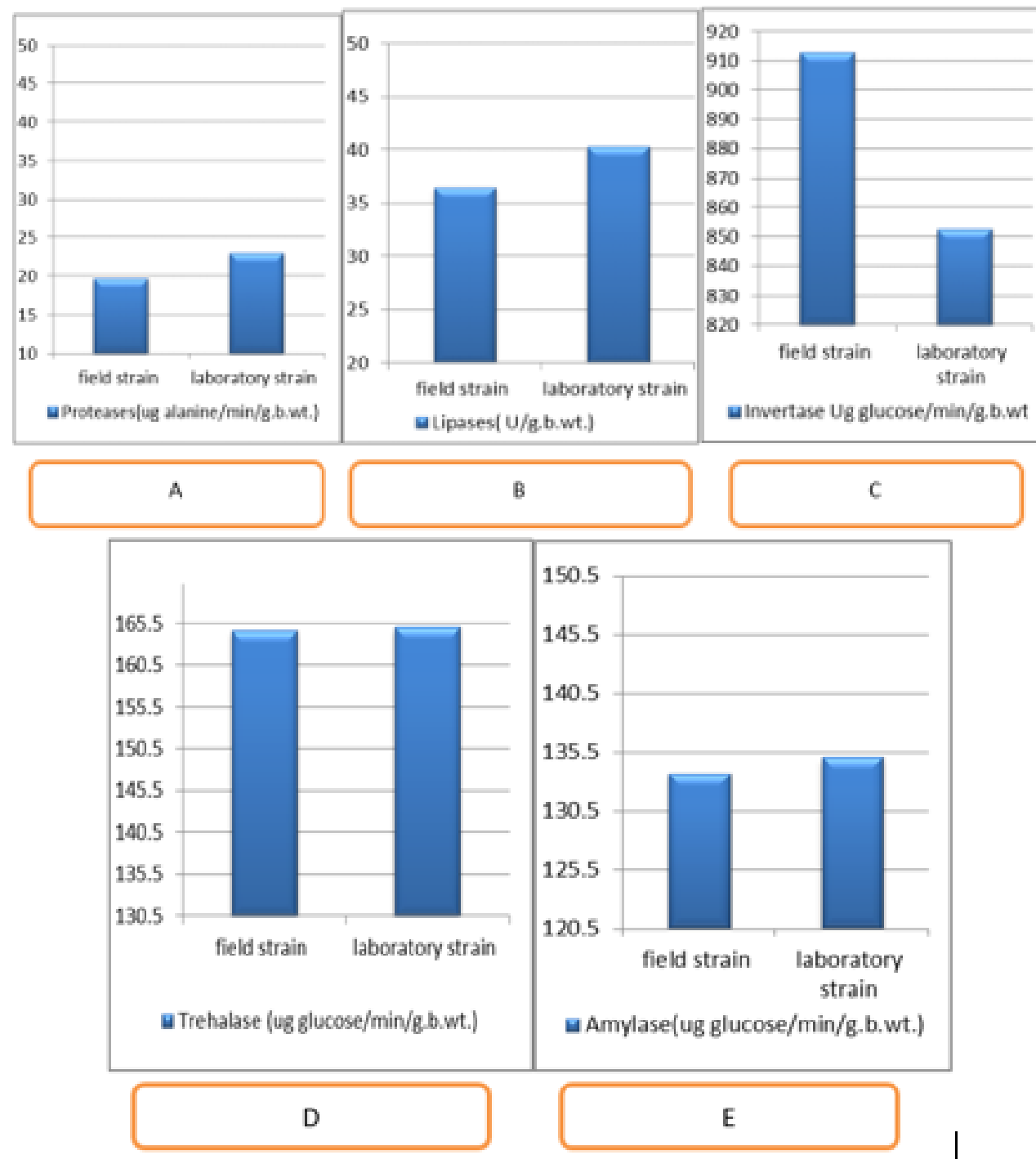

Fig. 3: The activity levels of digestive enzymes of $S$. littoralis $4^{\text {th }}$ larval instar for field and laboratory strains 
In the present study, it is clear in Table.3. \& Fig. 4 (A) that level of glutathione S- transferases (GSTs) enzyme increased significantly in field strain (47 \pm 1.53$)$ conjugated/min/g.b.wt, while its activity level decreased at laboratory strain (38 \pm 1.53$)$ conjugated/min /g.b.wt. respectively. There was a significant difference between them. Whereas, there were significant differences between field strain and laboratory strain. In contrast, Zhang et al., 2016 investigated that the activity levels of four antioxidant enzymes, including superoxide dismutase (SOD), catalase (CAT), glutathione ne-Stransferase (GSTs), and peroxidase (POD) under heat stress (0, 4, 12, 16, 20, 24 and $28^{\circ} \mathrm{C}$ ) for 4 and 12 hours, respectively they found that the activity of GSTs decreased obviously when the treatment temperature exceeded $24^{\circ} \mathrm{C}$. This result disagrees with our results seen in Table.3.

Activity levels of glutamic oxaloacetic transaminase (GOT) enzymes as seen in Table.3\& Fig. 4 (B) increased significantly at laboratory strain $(320.67 \pm 7.76)$ were as decreased in field strain (283 \pm 8.89$)$ (Ux103/g. b. wt.), respectively. Activity levels of glutamic pyruvic transaminase (GPT) enzymes as seen in Table.3\& Fig. 4 (C) gave no significant change between field and laboratory strain $(86 \pm 3.52) \mathrm{Ux} 103 / \mathrm{g}$. b. wt. (85.34 \pm 2.19$)$ Ux103/g. b. wt. respectively. While activity levels of (GPT) at field strain and laboratory strain were not significantly different.

Table 3: The activity levels of metabolic enzymes of 4th larval instars $S$. littoralis in field and laboratory strains.

\begin{tabular}{|c|c|c|c|}
\hline Strains & $\begin{array}{c}\text { GST (M mole sub } \\
\text { conjugated/min/g.b.wt) } \\
\text { Mean } \pm \text { S.E }\end{array}$ & $\begin{array}{c}\text { GOT -ALT } \\
\text { (Ux10/g.b.wt) } \\
\text { Mean } \pm \text { S.E }\end{array}$ & $\begin{array}{c}\text { GPT-AST } \\
\text { (Ux10/g.b.wt) } \\
\text { Mean } \pm \text { S.E }\end{array}$ \\
\hline Field strain & $47 \pm 1.53^{\mathbf{a}}$ & $283 \pm 8.89^{\mathbf{b}}$ & $86 \pm 3.52^{\mathbf{a}}$ \\
\hline $\begin{array}{c}\text { Laboratory } \\
\text { strain }\end{array}$ & $38 \pm 1.53^{\mathbf{b}}$ & $320.67 \pm 7.76^{\mathbf{a}}$ & $85.34 \pm 2.19^{\mathbf{a}}$ \\
\hline \multicolumn{2}{|r|}{ Note: Means with the same letter in the same row are not significantly different } \\
\hline
\end{tabular}

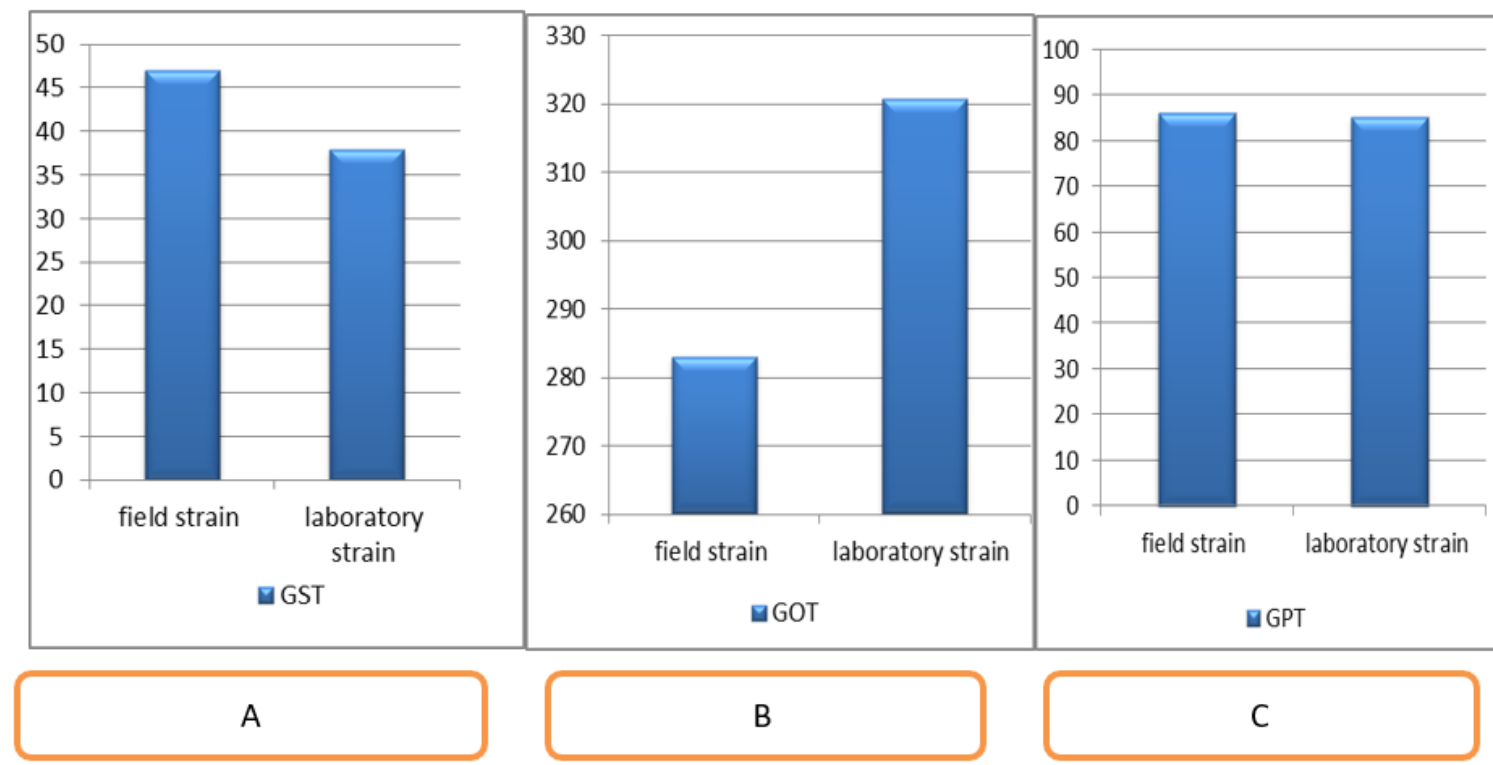

Fig.4: The activity levels of metabolic enzymes of $S$. littoralis $4^{\text {th }}$ larval instar for field and laboratory strains. 
Changes in the physiology of the nervous system and metabolism can be detected through the activity of acetylcholinesterase (AChE), alpha esterase (EST- $\alpha)$ and beta esterase (ESTß) Débora et al., 2016.

The results whereas, found in Table. 4 \& Fig. 5 (A and B) appeared that the Alpha (EST- $\alpha)$ and beta esterase (EST- $\beta$ ) enzyme increased significantly at field strain $(471.67 \pm 0.41) \quad \mathrm{Ug} \alpha-$ naphthol/min/g.b.wt. (264.67 \pm 7.43$)$ Ugß-naphthol/min/g.b.wt respectively
.Enzymes activity levels of alpha and beta decreased significantly at laboratory strain, they were $(327 \pm 7.58) \mathrm{Ug} \alpha$ naphthol/min/g.b.wt and $(236.34 \pm 3.72)$ $\mathrm{Ug} \beta$-naphthol/min/g.b.wt. The results indicated that the activity levels of these enzymes are more significant. In the present study, as cleared in Table. 4 \& Fig. 5 (C). AchE enzyme activity appeared non-significantly different between field and laboratory strain $(257.34 \pm 6.75) \mathrm{Ug}$ Ach Br/min/g.b.wt. and (235.34 \pm 6.36$)$ $\mathrm{Ug}$ Ach Br/min/g.b.wt respectively.

Table 4: The activity levels of acetylcholinesterase (AChE), alpha esterase (EST- $\alpha$ ), and beta esterase (EST- $\beta$ ) of $4^{\text {th }}$ larval instars $S$. littoralis in the field and laboratory strains

\begin{tabular}{|c|c|c|c|}
\hline Strains & $\begin{array}{c}\text { Alpha esterase (EST- } \alpha) \\
\text { Ug } \alpha- \\
\text { naphthol/min/g.b.wt } \\
\text { Mean } \pm \text { S.E }\end{array}$ & $\begin{array}{c}\text { Beta esterase (EST- } \beta \text { ) } \\
\text { Ug } \beta \text { - } \\
\text { naphthol/min/g.b.wt } \\
\text { Mean } \pm \text { S.E }\end{array}$ & $\begin{array}{c}\text { Ache } \\
\text { Ug Ach } \\
\text { Br/min } / \text { g.b.wt } \\
\text { Mean } \pm \text { S.E }\end{array}$ \\
\hline $\begin{array}{l}\text { Field strain } \\
\end{array}$ & $471.67 \pm 0.41^{\mathrm{a}}$ & $264.67 \pm 7.43^{\mathrm{a}}$ & $257.34 \pm 6.75^{a}$ \\
\hline Laboratory strain & $327 \pm 7.58^{\mathbf{b}}$ & $236.34 \pm 3.72^{b}$ & $235.34 \pm 6.36^{\mathrm{a}}$ \\
\hline
\end{tabular}

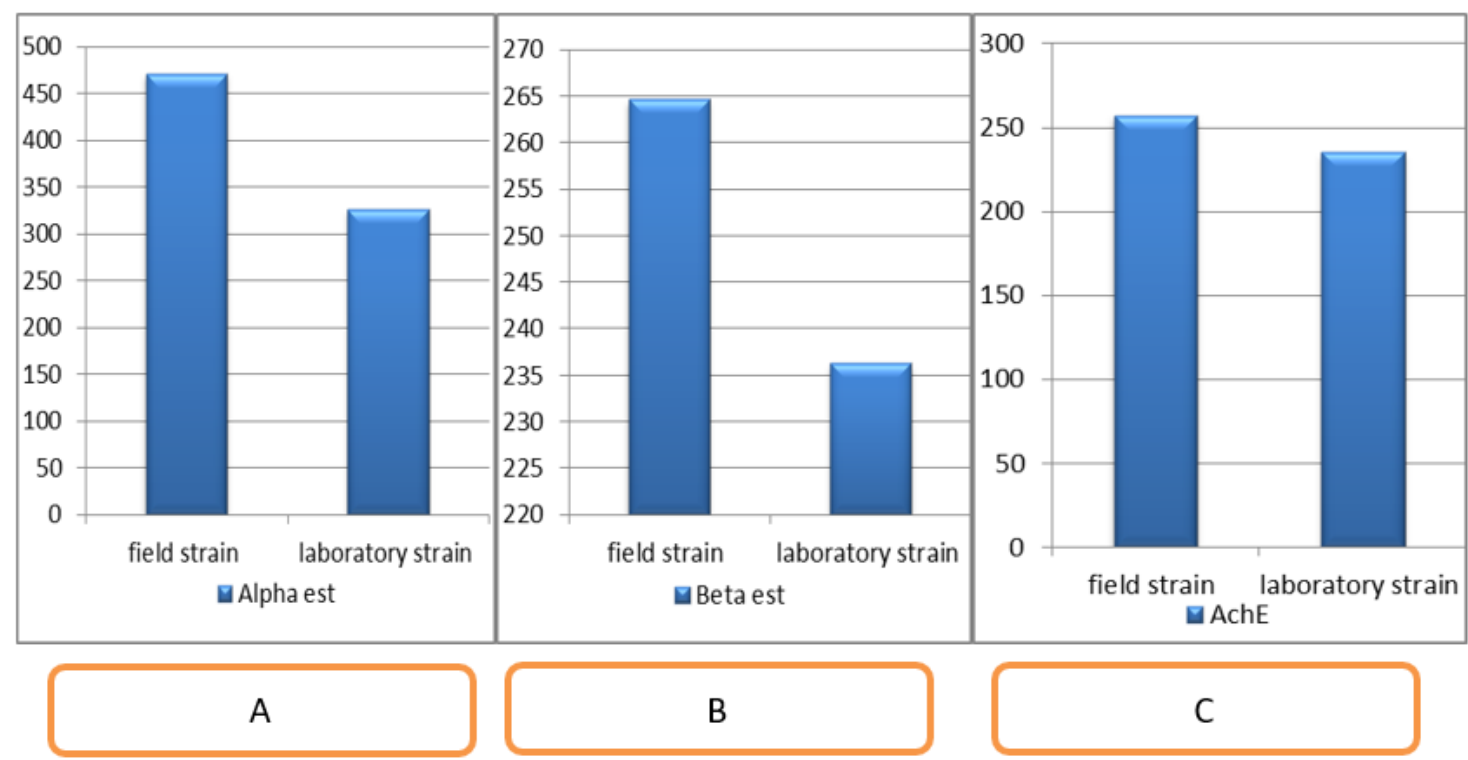

Fig. 5: The activity levels of acetylcholinesterase (AChE), alpha esterase (EST- $\alpha$ ), and beta esterase (EST- $\beta$ ) of $S$. littoralis $4^{\text {th }}$ larval instar for field and laboratory strains

Our results disagree with Debora $e t$ al., 2016 who concluded that AChE activity decreased at higher temperatures and corroborated the results of
Domingues et al., 2007 who observed the activity of the AChE of Chironomus. riparius Meigen, is higher at $6{ }^{\circ} \mathrm{C}$ and 16 ${ }^{\circ} \mathrm{C}$ than at $26{ }^{\circ} \mathrm{C}$. These results also 
disagree with the finding of Débora et al., 2016 who studied the effects of different temperatures on Chironomus sancticaroli where he found AChE activity decreased with increasing temperatures: at 20 and $25^{\circ} \mathrm{C}$, it was $69 \%$ and $59 \%$ lower than at $30{ }^{\circ} \mathrm{C}$, respectively. No significant changes in enzyme activity were detected between field strain and laboratory strain in the activity of EST- $\alpha$ were observed enzyme activity increased by $44 \%$ and $45 \%$ respectively. The enzyme activity of EST- $\beta$ was high at the field strain. At this strain, EST- $\beta$ activity was $24 \%$ higher than at the laboratory strain. Singh et al., 2013 concluded that Pricini when exposed to low-temperature causes alterations in the activity and kinetics of the tissue. Thus, AChE activity appears to be a potential biomarker towards the evaluation of the impact of cold stress on silkworms.

\section{REFERENCES}

Aida, S. K.; Walaa, E. G. and Dahi, H. F. (2018). Direct Effects of temperature changes on biochemical and enzymatic for cotton leafworm, Spodoptera littoralis (Boisd.). Egyptian Academic Journal of Biological Science, 11(1): 121-136

Ali, A.; Rashid, M. A. ;Huang, Q.Y.; Wong, C. and Lei, C. L. (2017). Response of antioxidant enzymes in Mythimna separata (Lepidoptera: Noctuidae) exposed to thermal stress. Bulletin Entomology Research Journal; 107(3):382-390.

Amin, T. R. (1998). Biochemical and physiological studies of some insect growth regulators on the cotton leafworm, Spodoptera littoralis (Boisd.). Ph.D. thesis, Faculty of science, Cairo Univ.

Angilletta, M. J. (2009). Thermal adaptation: a Theoretical and empirical synthesis. Oxford University Press, Oxford.

Asperen, V. K. (1962): A study of housefly esterase by means of sensitive colorimetric method. Journal of Insect Physiology, 8: 401-416.

Bale, J. S.; Masters, G. J.; Hodkinson, I. D.; Awmack, C.; Bezemer, T. M.; Brown, V. K.; Butter, F. J.; Buse, A.;Coulson, J. C. and Farrar, J. (2002). Herbivore in global Climate change research: direct effects of rising temperature on insect herbivores. Global Change Biology, 8: 1-16.

Berggren, A.; Bjorknam C.; Bylund, H. and Ayres M. P. (2009). The distribution and abundance of animal populations acclimate of uncertainty. OIKOS, 118(8), 1121-1126.

Bradford, M. M. (1976). A rapid and sensitive method for the quantization of Microgram quantities of protein utilizing the principle of protein-dye binding. Analytical Biochemistry, 72; 248-254.

Callaghan, A.; Fisher T. C.; Grosso, A.; Holloway, G. J. and Crane, M. (2002). Effect of temperature and pirimiphos-methyl on biochemical biomarkers in Chironomus riparius Meigen. Ecotoxicology and Environmental Safety, 52, pp. 128-133.

Coracini, M. D. A.; Zarbin, P.G.; Bengtsson, M. A.; kovaleski, A.; Vilela E. F.; Torezen, L. L. ; Hickel, E. R. and Witzgall, P.(2007). Effect of photoperiod and temperature on the development of Bonagotacr anaodes. Physiological Entomology, 32:394-398.

Costamagna, A. C. and Landis, D. A. (2004). Effects of food resources on adult Glyptapantales militaris and Meteorus communis 
(Hymenoptera: Braconidae), parasitoids of Pseudaletia unipuncta (Lepidoptera: Noctuidae). Environmental Entomology, 33: 128-137.

Crompton, M. and Birt, L. M. (1967). Changes in the amounts of carbohydrates, phosphagen, and related compounds during the metamorphosis of the blowfly, Lucilia cuprina. Journal of Insect physiology, 13:15751595

Cui, X. H.; Wan, F. H.; Xie, M. and Liu, T. X. (2008). Effects of heat shock on survival and reproduction of two whitefly species, Trialeurodes vaporariorum and Bemisia tabaci Biotype. Journal of Insect Science, 8, 1-10.

Dahi, H. F.; El-Sayed,Y.; El-Barkey, N. and Abd-El Aziz , M. (2009).Toxicological and biochemical studies of methylamine avermactin, a new type of bioinsecticid against the cotton leafworm, Spodoptera littoralis. Egyptian Academic Journal of Biological Science, (A.Entomology) 2:103-116.

Debora, R. B.; Vinicius, R. S.; Maiara, V. Guilosk, H. C.; Silvade, A. M., A. N. S. (2016). Factors that alter the biochemical biomarkers of environmental contamination in Chironomuss ancticaroli (Diptera: Chironomidae). Revista Brasileirade Entomologia, Vol. 60, (4), 341-34

Diffenbaugh, N. S. (2005). Fine-scale processes regulate the response of extreme events to global climate change, Proceeding of National Academic Science, U.S. A., 102, 15,774-15,778.

Domingues, I.; Guilhermino, L.; Soares, A. M. V. M. and Nogueira, A. J. A. (2007). Assessing
Dimethoate contamination in temperate and tropical climates: Potential use of biomarkers in bioassays with two chironomid species. Chemosphere, 69(1), 145-154.

Dooremalen, A. C. V.; Koekkoek, B. J. and Ellers, A. J. (2011): Temperature- induced plasticity in membrane and storage lipid composition: Thermal reaction norms across five different temperatures. Journal of Insect Physiology, 57: 285-291.

Dubios, M.; Gilles, K.A.; Hamilton, J.K.; Rebers,P.A.andSmith,F.(1956).

Colorimetric method for determination of sugars and related substances. Analytical Chemistry. 28:350-356.

Easterling, D. R.; Meehl, G. A.; Parmesan C.; Changnon, S. A.; Karl, T. R. and Mearns,L.O. (2000).Climate extremes: observation modeling, and impacts .Science, 389:20682074.

El-Aswad, A. F.; Abdelgaleil, S. A. M. and Nakatani, M. (2003). Feeding deterrent and growth inhibitory properties of limuloids from Khaya senegalensis against the cotton leafworm, Spodoptera littoralis. Pest Management Science, 60, a199-203.

Ehsan, B. M.; Izadi, H. Samih, A. M.; Moharramipourt and Mahdian, K. (2011). Effect of insect growth regulators, temperature and overwintering on larvae of pistachio leaf white borerm, (Ocneria terebinthina). International Journal of Agriculture Biology, Vol. 13, No. 3, 33-43

Ellis, J. r. j. D.; Neumann,R.H.and Elaz, P. J. (2002). Longevity and Success of Aethina tumida (Coleoptera: Nititulidae) fed 
different natural reproductive diets. Journal of Economic Entomology, 95:902-907.

Englund, G.; Ohlund, G.; Hein, C. L. and Diel, S. (2011). Temperature dependence of the functional response.Ecology letters, 14, 914-921.

Gamil, W. E. (2004). Production of some bio-formulations and study of their efficiency on some physiological traits in some insect species. Pp 32. M. Sc. Faculty of Agriculture Ein Shams University, Egypt. 135pp.

Gullan, P. J. and Cranston P. S. (2005). The insects: an outline of entomology. $3^{\text {rd }}$ ed. Black well Publishing Ltd., Davis, USA.

Habig, W. H.; Pabst, M. J. and Jakoby, W. B. (1974). Glutathione Stransferase the first enzymatic step in mercapturic acid formation. Journal of Biological Chemistry, 249(22): 7130-7139.

Hachiya, T.; Terashima, I. and Noguchi, K. (2007) Increase in respiratory cost at high temperature is attributed to high protein turnover cost in Petunia $\mathrm{x}$ hybrid petals. Plant Cell and Environment, 30, 1269-1283.

Hag, C.; Steel, D.; Marchand I.; Seiber, C. and Brody, D. (2004). Integrating the art and Science of medical practice innovations in teaching medical communications skill family medicine, 36(1; suppl), pp.4350.

Hansen, J. D.; Johnson, J. A. and Winter, D. A. (2011). History and use of heat pest control: a review. International Journal of Pest Management, 57, 267-289.

Hochachka, P. W. and Somero, G. N. (1973). Strategies of biochemical adaptation. WB Saunders, Philadelphia, 16.
Hochachka, P. W. and Somero, G. N. (2002). Biochemical adaptation: mechanism and process in physiological evolution. New York: Oxford University Press.

Ishaaya, I.; Moore I. and Joseph, D. (1971). Protease and amylase activity in larvae of the Egyptian cotton leafworm, Spodoptera littoralis. Journal of Insect Physiology. 17: 945-953.

Ishaaya, I. and Swirski E. (1976). Trehalase, invertase and amylase activities in the black scale, Saissetia oleae, and their relation to host adaptability. Journal of Insect Physiology, 22: 1025-1029.

Kar, P. K.; Srivasta, P. P.; Sinha R. K. and Sinha, B. R. R. P. (1994). Protein concentration in the pupal haemolymph of different races and F1 stop cross of Antheraea myllitta D. Indian Journal of Service, 33(2):174175.

Khrüt, U.; Samietz J .and Dorn S. (2006). Thermal response in adult codling moth. Physiological Entomology, 31: 80-88. |

Kingsolver, J. G. (2006). Thermal reaction worm for caterpillar growth depends on diet. Evolutionary Ecology Research. 8:703-715.

Kiran, k. N.; Ismail S. M. and Dutta, A. (1998). Different tail uptake of storage protein by the fat body of Rice moth, Corcyra cephalonica during the larval pupal Develop. Entomology, 23: 83-90.

Knight, J. A.; Anderson S. and Rawle J. M. (1972): Chemical basis of the sulfophospho-vanillin reaction for estimating total serum lipids. Clinical Chemistry, 18: 199-202.

Lale, N. E. S. and Vidal, S. (2003). Effect of constant temperature and 
humidity on oviposition and Callosobruch hussubinnotatus (pic) on Bambara Groundnut, Vigna subterranean (L.) verdcourt. Journal of stored Product Research, 39:459-470.

Lee, H., Stultz, B. G., Hursh, D. A. (2007). The Zic family member, odd-paired, regulates the Drosophila BMP, Decapenta plegic, during adult head development. Development, 134(7): 1301--1310.

Lee, K. P. and Roh, C. (2010). Temperature-by-nutrient interactions affecting growth rate in an insect ectothermic. Entomologia Experimentalis Applicate, 136, 151-163.

Lee, K. P.; Raubenheimer, D. and Simpson, S. J. (2004). The effects of nutritional imbalance on compensatory feeding for cellulose-mediated dietary dilution in a generalist caterpillar. Physiological Entomology, 29, 108-117.

Lee, Y. P. and Takabashi, T. (1966). An improved colorimetric determination of amino acids with the use of ninhydrin. Analytical Biochemistry, 14: 7177.

Lemoine N. P., and Burkepile D. E. (2012). Temperature-induced mismatches between consumption and metabolism reduce consumer fitness. Ecology, 93, 2483-2489.

Malik, M. A. and Malik, F. A. (2009). Oncogenic changes in haemolymph biochemical composition in the Silkworm, Bombyx mori L under thermal stress. Academic Journal of Entomology, 2 (1): 16-21.

Martin, M. D. (1969). Developmental changes in the late larva of Calliphora stygia-II. Protein synthesis. Australian Journal of
Biological Sciences, 22: 935945.

Michiyo G., Mitsuhiro F., Koichi S. and Masato S. (1997). Factors affecting carbohydrate and free amino acid content in overwintering larvae of Enosima leucotaeniella. Journal of Insect Physiology. Vol. 44, (1), 87-94.

Mukanganyama, Z. B.; Fathipour, Y.; Khanjani, M.; Moharramipour S. and Zaluki, M. (2010). Preimaginal development response to constant temperatures in Hypera postica (Coleoptera: Curculionidae): picking the best model. Environmental Entomology, 39: 177-189.

Nagata, M. and Kobayashi, M. (1990). Effects of nutrition on storage protein concentration in the larval haemolymph of silkworm, Bombyx mori L. Journal of Sericulture Science Japan, 59: 469-474.

Naumff, D. G. (2001). $\beta$-Fructosidase superfamily: homology with some $\alpha$-L- arabinases and $\beta$-D xylosidases. Protein Structure Functions and Gene, 42:66-76

Neven, L. G. (2000). Physiological responses of insects to heat. Postharvest. Biology and Technology, 21:103-111.

Parmesan, C., and Yohe, G. (2003). A globally coherent fingerprint of climate change impacts across natural systems. Nature, 421: 3742.

Parmesan, C. (2006). Ecological and evolutionary responses to recent climate change. Annual Review of Ecology, Evolution, and Systematic, 37, 637 - 669.

Pant, R. and Gupta, D. (1979). The effect of exposure to low temperature on the metabolism of carbohydrates, lipids and 
protein in the larvae of Philosamia ricini $\mathrm{R}$. Journal of Bioscience, Vol. 1, No. 4, 441446.

Pineda, S.; Budia, F.; Schneider, M. I.; Gobbi, A.; Vinuela, E.; Valle J. and Del Estal, P. (2004). Effect of two bio rational insecticides, Spinosad and memethoxy fenozide, on Spodoptera littoralis (Lepidoptera: Noctuidae) under laboratory conditions. Journal of Economic Entomology, 97 (6): 1906-1911.

Reitman, S. and Frankel, S. (1957). Colorimetric method for aspartate and alanine transaminases. American Journal of Clinic Pathology, 28: 56

Rinehart, N. J. ; Bradshaw, J. L. ; Moss, S. A.; Brereton A. Y. and Tonge, B. J. (2000). Atypical interference of local detail on global processing in highfunctioning autism and Asperger's disorder. Journal child psychology psychiatry, ; 41(6):769-778.

Simpson, D. R.; Bull, D. L. and Lindquist, D. A. (1964): A semi micro technique for the estimation of cholinesterase activity in bull weevil. Annual Entomology Society of American, 57 (3):367- 377.

Singh, A.; Sunil, K.; Jaiswal, and Sharma, B. (2013). Effect of low temperature stress on acetylcholinesterase activity and its kinetics in $5^{\text {th }}$ instar larvae of Philosamia ricini. Journal of Biochemistry Research, Vol. 1(2), pp.17-25.

Sonmez, E. and Gulel, A. (2008). Effect of different temperatures on the total Carbohydrates, lipids and proteins amount of the bean beetles, Acanthoscelides obtectus say (Coleoptera: Bruchidae). Pakistan Journal of
Biological Science, V.11, $\mathrm{N}: 14,1803-1808$.

Srinivasan, S.; Dorighi, K. M. and Tamkun, J. W. (2008). Drosophila Kismet regulate shist one H3 lysine 27 methylation and early elongation by RNA polymerase II. PLOS Genetics, 4(10): e1000217.

Stone A. C., Gehring C. A. and Whitham, A. (2010). Drought negatively affect communities on a foundation tree Growth ring predict diversity. Oecologia, 164,751-761.

Takaya, I. (2005). Intrinsic optimum temperature for development of insects and mites. Environmental Entomology,34 (6)1377D1387.

Tatchell, R. J.; Araman, S. F. and Boctor, F. N. (1972): Biochemical and physiological studies of certain Ticks (Ixodoidea). Z. Parsitenk. Journal of Medicine entomology, Vol 39:345- 350.

Taveras, R.; Hilje, L. and Carballo, M. (2004). Development of Hypsipyla grandella (zeller) (Lepidoptera: Pyralidae) in response to constant temperatures. Neotropical Entomology, 33:1-6.

Terra, R. W. and Ferreira, C. (2012). Biochemistry and molecular biology. Insect Molecular Biology and Biochemistry, pp.365-418.

Wilce, M. C. and Parker M. W. (1994). Structure and function of glutathione S. transferases. Biochimica et Biophysca Acta, 16; 1205(1):1-18.

Willmer, C. W.; Stone, G. and Johnston, I. (2004). Insecticidal action. Proceeding of $4^{\text {th }}$ International Congers for Biochemistry, Environmental physiology of animals, (Oxford: 201-210. 
Blackwell Science).

Zhang, Q.; Tu, Y. Q.; Liu, H.; Zhang, D.; Zhang H.; Zhang, W. J. and Qin Y. S. (2016). Effects of temperature stress on antioxidant enzymes in
Hepialusxia ojinensis (Lepidoptera: Hepialidae) larva. Journal of Environmental Entomology, Vol.38 No.1 pp.47-53

\section{ARABIC SUMMARY}

ردود الافعال البيوكيميائية والفسيولوجية للسلالة الحقلية لاودة أوراق القطن كاستجابات للتعرض لارجات

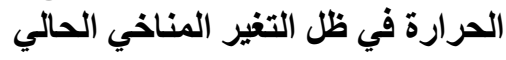

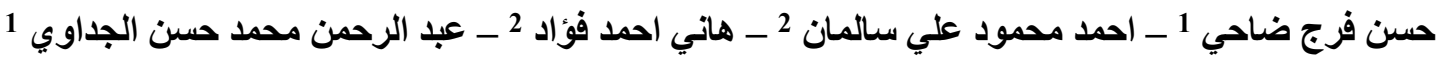

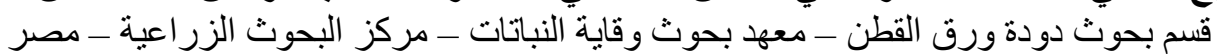

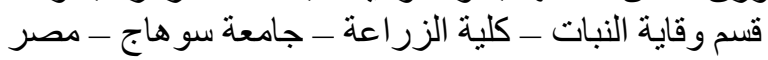

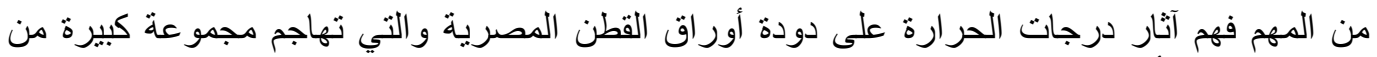

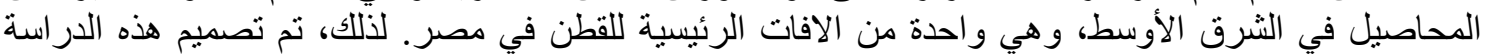

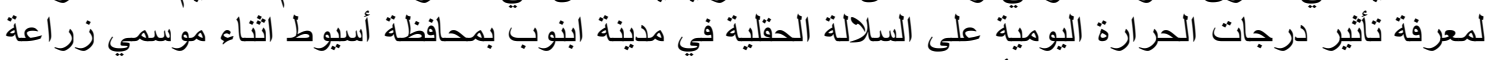

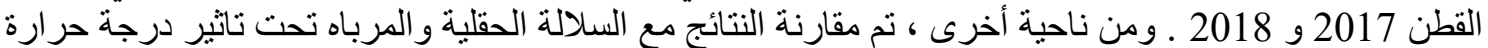

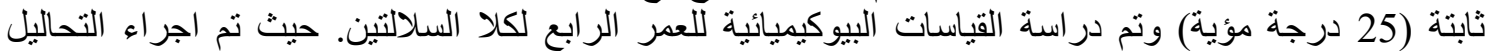

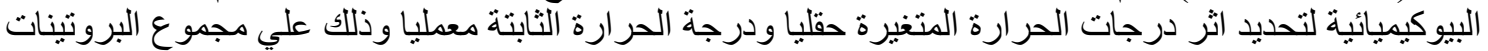

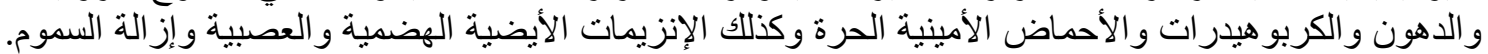

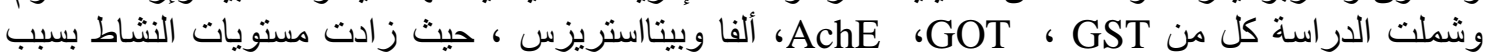
الاجهاد الحقلي .بينما انخفضت الأحماض الأمينية الحرة ، و البروتينات الكلية ، و البروتينيز ، و و الليباز ، و والأميلاز

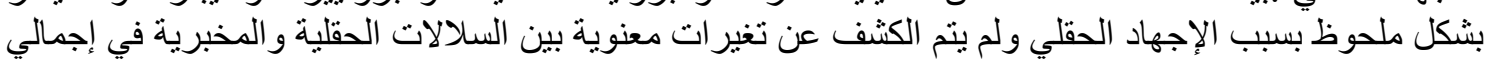
الكربو هيدرات و الدهون الكلية ، و التزياليز ، و و GPT. 